\title{
Female Micro-enterprises in Rural Central Chile. Construction and Reconstruction of the Role of Women in Agriculture. A Case Study
}

\author{
By Julia Fawaz* \\ Paula Soto ${ }^{\dagger}$ \\ Rosana Vallejost
}

In recent decades, rural areas in Chile and Latin American, largely product of globalization and modernization of society, have been undergoing substantial transformations, influence each other. This paper argues that rural female work paths and meanings associated with work and family are undergoing deep transformation in Central Chile as a result of the rural/urban spatial mobility derived from labor, education and consumer reconfigurations. The study is conducted in Nuble province, which exhibits high rural population and intermediate cities and towns with a historic, structural and symbolic linkage with the rural environment. The analysis is done from recent statistics and a survey to a sample of 248 rural women applied in 2011. Results show the increasing feminization of agricultural labor at expense of male employment, a female greater visibility in productive and social organizations at local level, rural family restructuring which show some tendencies similar to urban paths, and changes in traditional rural/urban linkages.

Keywords: Female work, Micro-enterprises, Labor market, Rural central Chile

\section{Introduction}

Female work has grown substantially in Chile during recent decades although women participation is still low according to the Organisation for Economic Cooperation and Development (OECD) and Latin-American contexts. Significant gender gaps exist at the socioeconomic and educational levels for the incorporation of women in the labor market, which is also affected by children at home, family life cycle, home structure, job opportunities, women's preferences and attitudes, and predispositions of the near environment. Although female work participation is higher in urban areas, rural women are also increasing their involvement in paid work. Even though peasant women have always performed productive work as part of their gender role, paid work involves other aspects, such as improved self-esteem, greater personal freedom, new social relationships and situations of autonomy that directly impact personal identity, family and community situations and the country development.

\footnotetext{
${ }^{*}$ Professor, Bio-Bio University, Chile.

${ }^{\dagger}$ Professor, Bio-Bio University, Chile.

* Professor, Bio-Bio University, Chile.
} 
Considering the new rural reality and the global transformations of work, this article analyses the increasing inclusion of rural women in the labour market, particularly their transition from peasant housewives to microentrepreneurs and the impact this new role has on themselves and in their immediate contexts. Although the inclusion of women in the labour market is decisive, regardless of their occupation, our hypothesis is that microentrepreneurship is a labour strategy that allows a better work/family balance. This also implies a transformation in the role of women, traditional gender relationships, and rural family organisation.

The analysis is based on a case of women flower micro-entrepreneurs located in the province of Nuble, central Chile. An in-depth study of rural micro-entrepreneurs profile is performed, including women's motivations, the value and meaning they give to work, and the transformations this new role generates in family and community structures and dynamics. The analytical design includes four phases. The first reconstructs some theoretical reflections about the object of study. The second describes the methodology and spatial context. A third examines the trajectory, dynamics and development of the micro-enterprise under study. Finally, based on the narratives of the rural women, we analyse the transformations and tensions they live as microentrepreneurs and the meanings they construct and reconstruct on different scales.

\section{Theoretical/Conceptual Approaches}

\section{Female Work and Micro-enterprise}

Participation of women in the workforce has increased in Chile since the 1980s. Even though a broad consensus supports this process, legal, economic, and especially cultural barriers still persist, which impede an equitable inclusion of women in the labour market.

Numerous studies have addressed the topic of gender equity and female labour assigning to the last a significant role as mechanism of female empowerment, since it improves self-esteem and constructs greater spaces of autonomy (Amorós et al. 2011, Deere 2006, García and Oliveira 2004, SELA 2010, SERNAM 2008). It has also been recognized that access to work is consistently more difficult for women than for men regardless the country level of development, because of family responsibilities, deficient skills and qualifications or social and cultural barriers. However, inclusion of women in paid work is persistently increasing in both salaried and entrepreneurial occupations, and evidence indicates similar trends in rural sectors (Anthopolou 2010, Chiappe and Zapata 2010, Fawaz and Rodríguez 2013, Fawaz and Soto 2012, Giraldo 2010, Vera and Moreira 2009).

Economic organisations are currently confronted with a context of accelerated change in which new competitors, products and services continuously appear. New companies enter and leave the market rapidly, and permanent job positions are more and more difficult to create and maintain, 
and this result in more flexible but more precarious jobs. In this new scenario, the micro-enterprise has some opportunities, since as small and flexible units, they can respond quickly to the fragmentation of the production process and to fluctuating demands. The persistent challenge that remains is to increase their technological and productive standards so that micro-entrepreneurs can sustain their activity (Amorós et al. 2011, Berdegué 2001, Giraldo 2010, Sela 2010, Valenzuela 2005, Vera and Moreira 2009).

There are various definitions of micro-enterprise (ME). For purposes of this study, ME is a unipersonal company or one with less than nine contracted workers and a micro-entrepreneur with incomplete higher education. In Chile they represent almost $80 \%$ of the formally established enterprises, providing occupation to approximately $40 \%$ of the labor force, although their participation in the country's total sales does not exceed $5 \%$. It is so a major economic actor gaining relevance in the public agenda. In fact, a relatively formal sector of small and micro-enterprises is being established and those led by women are exhibiting significant progress (OIT/SERCOTEC 2010, SERNAM 2008, Valenzuela 2005).

\section{Rural Female Micro-enterprises}

The entrepreneurial option is a means of personal and family subsistence for an ever-increasing number of women. Chilean women entrepreneurs represent today $33 \%$ of all entrepreneurs compared with $20 \%$ in 2003 , so improving women vital contribution as providers and as economic agents (SELA 2010, APEC 2009, Valenzuela 2005).

The specialised literature has concluded that female micro-enterprises are different from those headed by men. Firstly, most of them are a result of necessity rather than vocation; they appear as a better option than a full time job which requires leaving home or an inflexible schedule. Secondly, women have much smaller "businesses" and more limited capital, taking advantage of traditional know-how, everyday skills and domestic spaces. Thirdly, many of them operate in the informal economy, focusing on low-profit sectors and a limited range of products. Moreover, women micro-entrepreneurs often perform all the enterprises functions, so the marketing and management function are deficient and production is therefore targeted to local markets, tourism, or restricted exports. Although networking is essential, it is scarce. Finally, depending on the sociocultural and legal environment, men often control women's income (OIT/SERCOTEC 2010, SELA 2010, SERNAM 2008, Valenzuela 2005).

Rural female micro-enterprises face both economic and cultural obstacles. In addition to the general difficulties of micro-enterprises, there are gender obstacles that are deep-seated in the rural sector. In spite of a "politically correct" discourse, sexist stereotypes persist, gender division of domestic labour has not significantly changed, and women have less control of the public sphere, less access to resources and markets and less freedom of movement. Additionaly, women have difficulties for preparing an autonomous entrepreneurial project, financially independent of the family budget, since it is 
carried out in domestic spaces, without adaptation of traditional gender roles to new labour realities. Given this situation, women cannot regularly dedicate themselves to the productive activity and cannot be properly trained. On the other hand, the micro-entrepreneurial activity can provide advantageous opportunities for women. Since leaving home is not required, women will probably meet less resistance from husbands and partners. They can even rely on the support of husbands and children with better education and management skills, especially when women's income complements low agricultural production cycles. micro-enterprise can also be an option for women with small children or low education, even older women, provided they have an organisation and technical support (Amorós et al. 2011, Anthopolou 2010, Chiappe and Zapata 2010, Fawaz and Soto 2012, Valdés 2007).

These trends are expressed at cultural level in the meanings and imaginaries women construct to give sense to their reality. We postulate that work plays an important role in giving meaning to everyday life by providing multiple guiding principles, while bringing about a new world, new sociabilities, and a greater sense of autonomy. Nevertheless, work does not replace but rather complements the family space as a relevant identity reference framework, influencing personal biographies and trajectories as well as family and immediate social environment (Fawaz and Soto 2012, García and Oliveira 2004, Godoy et al. 2007, Guadarrama and Torres 2007, Soto and Fawaz 2006). Tarrés (2007) states that the breakdown of structural processes, such as the case presented in this article, opens the possibility of reconstructing prior cultural arrangements and responses.

\section{Methodology}

\section{Spatial Context of the Study}

The case we are analyzing is located in the province of Nuble, Bíobio Region, central Chile, more specifically in the commune of San Ignacio, which exhibits high levels of rural population and poverty. Nuble has $34 \%$ of rural population, compared with $14 \%$ for the country, and $70 \%$ for San Ignacio (Figure 1). 
Figure 1. Study Site

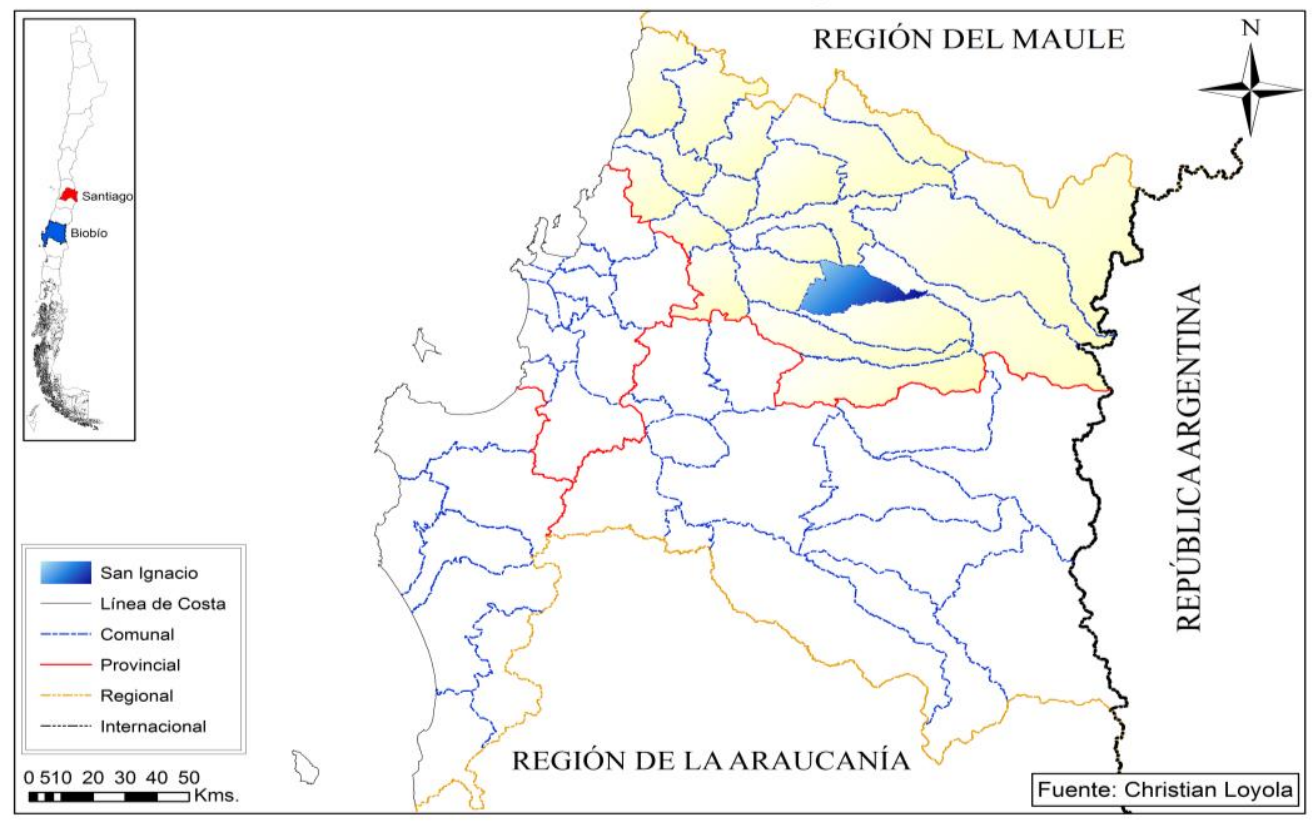

Source: Fieldwork survey data 2014.

Significant modernisation processes are noted in rural Nuble and in San Ignacio, which are expressed in a new rurality and restructurings in different areas of rural life. We observed improvements in most indicators of quality of life and agricultural activity, most relevant in this province, and female work has increased steadily in the last two decades in a context of decreasing male occupation particularly in agriculture (GORE 2010, INE 2002). This greater presence of women in the labour market arises from personal initiatives as from institutional programmes, suggesting a reorientation of public policies. Male farmers were the direct beneficiaries in the past, but now women are also considered in both social and productive programmes ${ }^{1}$.

Nationally, there are approximately 1,352,000 microenterprises of which $37.3 \%$ are lead by women. In Nuble, women led $29.0 \%$ of the 35,110 microenterprises and only $20.6 \%$ of these are rural.

\footnotetext{
${ }^{1}$ Most programmes and instruments designed to support rural women's micro-enterprises operate through agencies of the Ministry of Agriculture, such as the Institute of Agricultural Development (INDAP) and the Foundation for Agrarian Innovation (FIA). The use of the credit programme of INDAP by female ME has increased significantly, as well as the programmes to strengthen rural women skills, personal development, and entrepreneurship abilities. In the area of innovation, FIA promotes initiatives for sustainable development and competitiveness of the agrifood and forestry sector, including ME, and rural women can be eligible for funding of innovation projects, technological tours, and specialized consultancy. Other public agencies have instruments to orient the development of micro-enterprises and support its presence in external markets. (SELA 2010, MINAGRI 2009, Daeren 2001).
} 


\section{Methodological Approaches}

Our methodological approach combines quantitative and qualitative methods and techniques in order to organise two levels of analysis that allowed us to address the proposed objectives.

First, there is a structural approach that acknowledges a process of rural modernisation, analysing the global dynamics of work and the country's microentrepreneurial sector, particularly the situation of women. This analysis uses statistical information from population and agricultural censuses, official periodic surveys, and our own survey to a sample of 248 rural women that was conducted between January and March 2011.

Second, there is a micro-social observation to reconstruct the trajectory of the flower microenterprise under study. We used documentation from the Department of Rural Action (DAR) of the Diocese of Chillán, micro-enterprise records, and interviews of professionals who supported the organisation from its start-up to its consolidation. The qualitative analysis is also constructed through the narratives of the women micro-entrepreneurs of San Ignacio, obtained through three semi-structured interviews and two discussion groups conducted in December 2010 and December 2011. We reintroduce the experience and meaning that women expressed about work, family, and gender relationships.

These empirical observations are complemented by the construction of a conceptual framework supported by studies and bibliography about rural entrepreneurship in order to enlighten findings and generalise conclusions.

\section{Female Micro-entrepreneurship in Nuble. The Case of Women Flower Producers}

\section{Entrepreneurship in the Rural Environment: Challenges, Findings, and Learning}

Neighbourhood Union $\mathrm{N}^{\circ} 1$ of San Ignacio commune is an organisation mostly made up of women related to productive activities of the agricultural sector. It graphically reflects the challenges and learning experienced by the women and their families in the process of joining the workforce. Since its inception, the Neighbourhood Union was the initial platform for creating initiatives related to rural development and women's micro-entrepreneurship.

Origin, Development, and Characteristics of Micro-entrepreneurship in Rural Areas

Promoting rural development at the communal level goes back to work achieved by the Department of Rural Action (DAR) of the Diocese of Chillán in 1987. DAR was created in 1976 to support peasant farmers of Nuble during a period of conflict in Chile. Its activity focused on the planning, organisation, and implementation of initiatives to assist the rural population based on a collaborative integral work model that considered: i) education, ii) agrotechnical and organisational training, iii) technical and organisational 
consultancy, and iv) credit with funds from international cooperation (Pucheu 2009). The origin and development of rural organisations is tied to on-site work by various types of agents, such as DAR, international NGOs, and the Chilean State through local governments and INDAP (Bebbington 1997, Bebbington and Sotomayor 1998, Escobar 2002).

Phase 1: Forming the Bases of Rural Organisations

Between 1987 and 1991, the work done by DAR was concentrated in three areas: a) promoting human development activities, b) productive development, and c) organisational support.

In the area of human development, activities focused on workshops to enhance the skills and abilities of the rural population, strengthen their identity as peasant farmers, and promote inclusive development.

For productive development, work focused on actions to improve production of traditional crops, such as wheat and potato, through direct consultancy from a team of agronomists and extension workers that concentrated on stimulating the inclusion of technologies in the peasant farmer production systems.

For organisational support, DAR prompted actions to promote participation in local organisations as a mechanism to access to projects and resources from international cooperation. During the first two years, the community organised informal groups and later acquired a better organisational structure through the Local Peasant Farmer Communities Projects (Fawaz and Rivera 1986). These Peasant farmer committees met monthly to address technical/productive and organisational topics. Both participation in the decision of providing credit to the associates and coordination of training activates were delegated to the committees (Pucheu 2009). The peasant farmer organisations counted on the support and stimulation of intermediary agents that fostered abilities in the rural population to promote the development of associative micro-entrepreneurship initiatives (Berdegué 2001, Fawaz et al. 2012, Uphoff et al. 1998). At this stage, women's participation in peasant farmer committees is still limited and the discussion of productive projects is led by the heads of families (Figure 2).

\section{Phase 2: Generating Productive and Marketing Abilities in Local Farmers}

Since 1990, the State plays a leading role in promoting production by increasing spending and public investment in programmes to support smallholder agriculture. This meant focusing on actions to strengthen marketing of local production where producer participation in technology transfer programmes (TTP) financed by INDAP and the access to credit became key elements in the development of peasant farmer enterprises (Berdegué 2001, Escobar 2002).

In this context, DAR prepared a Peasant Farmer Development project aimed at improving production, productivity, and marketing of agricultural products to strengthen the peasant farmer organisation, including women and youth. For the first time, a productive programme for rural women is 
established aimed at supporting their work on the farm and providing them with entrepreneurial management tools. Further support was provided by INDAP's Enterprise Development Fund (FODEM) to promote strategic development of the producer organisations. Once this project ends, DAR starts to close its participation on communal level and initiates a gradual process of transferring skills to local leaders.

Meanwhile, women play a greater role in the rural organisations by participating in health and basic sanitation programmes and entrepreneurial skills training. They participate in training workshops for handicrafts, food conservation, and vegetable and flower production. The latter is the area where they acquire better skills and organise themselves to obtain financing for supplies and materials, including a cold chamber, to maintain and protect flower production whose target markets were the main cities of the Bíobio Region.

Figure 2. Evolution of Women's Micro-entrepreneurship Initiatives in San Ignacio
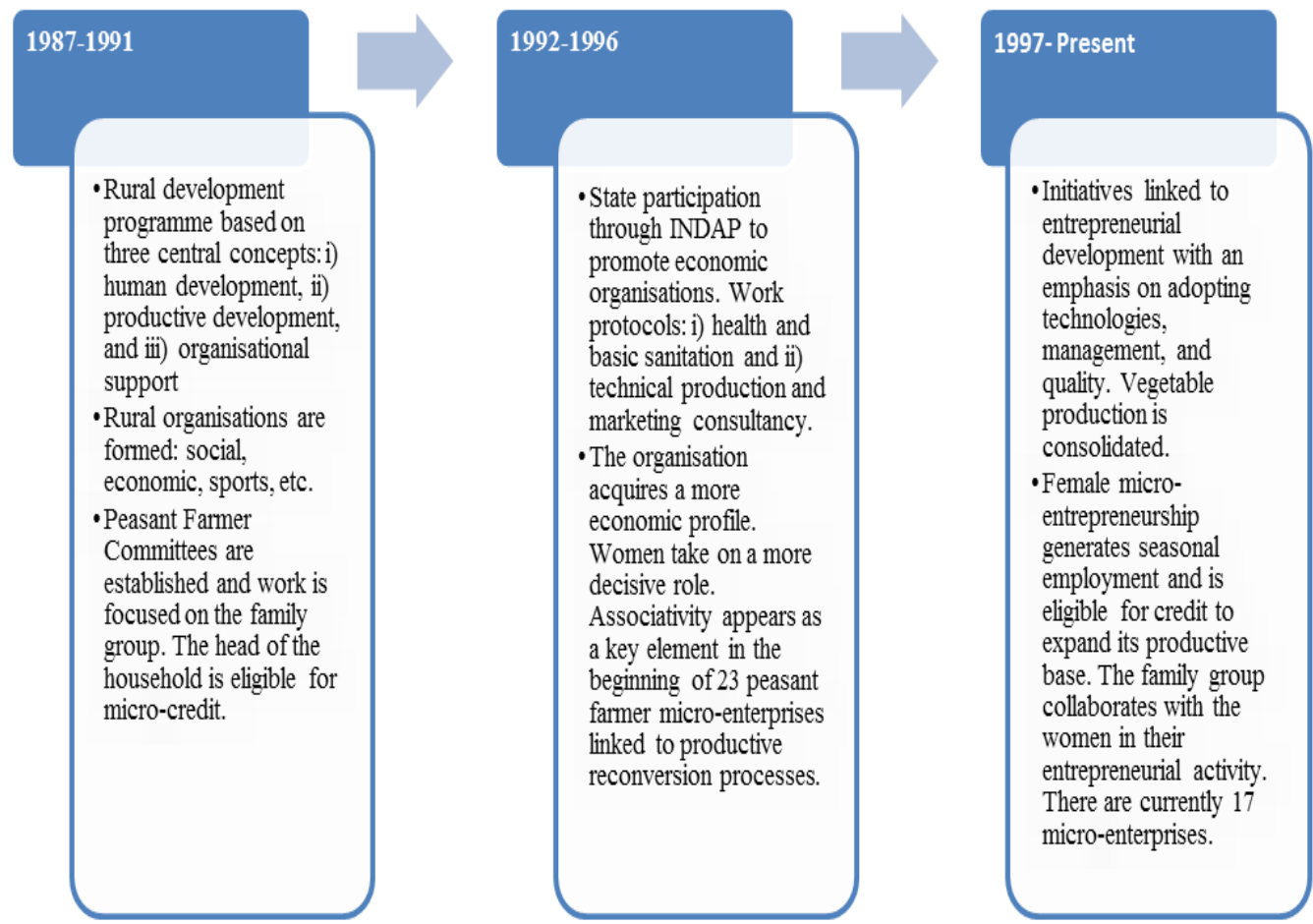

Source: Compiled from information collected on site.

Phase 3: Consolidating Entrepreneurship Initiatives in Agriculture

From 1997 onward, the associative work of women belonging to Neighbourhood Union $\mathrm{N}^{\circ} 1$ bore fruit; the group's efforts focused on greenhouse vegetable and flower production. Since then, the priority has been to incorporate technology to improve irrigation, establish controlled environments in the greenhouses and have access to training in entrepreneurial management. Training programmes have fostered technical/productive, managerial/administrative, and organisational aspects to strengthen the development of this economic activity. 
There are now only 17 of the 23 micro-enterprises that started up at the beginning of the 1990s, they have an annual operational margin fluctuating between 15 and 50 million CLP. Most of the micro-enterprises associated with vegetable production operate under the contract model of agriculture where producers and agroindustry work together to reach better levels of coordination and integration in the production chain.

Finally, the trajectory of the San Ignacio micro-enterprises reflects how the action of various NGOs contributed in accelerating the participation and development process of women in producer organisations. By generating strategies to diversify family income, they have developed local entrepreneurship initiatives that has involved networking with other organisations to search for information, knowledge, and support for their production efforts. The women of San Ignacio have gone from being invisible in their contribution on the farm to playing a significant role in the productive activity and thus achieve greater autonomy in their enterprise. Experience accounts for a way of reflecting the transformations in Chile's rural population today in addition to the existing dynamics and changes in the relationships between men and women, both domestically and outside the family.

\section{Meaning of Micro-enterprise Activity and Family Restructuring}

The new realities experienced by this group of micro-entrepreneurs are registered at different transformation levels and even in the continuity of their daily lives. We will therefore present some core meanings where the main logic is given by the women micro-entrepreneurs' observation and discourse related to three areas in the production of individual and collective meanings, which are symbolically efficient while providing order and a sense of certainty (Jiménez and Belén 2005). We refer to scales to distinguish the levels in which the transformations experienced by this group are registered. According to Smith (1993), the concept of scales is related to the geographic resolution of contradictory processes of competition and cooperation. In our case, this concept helps to establish limits between the different situations of these women's experience where subjective tensions affect their identity processes.

\section{Body /Individual Scale}

Rural women have been historically associated with food production and agriculture, simultaneously playing productive and reproductive roles necessary for the peasant farm production unit. However, while this "work" was taking place in the household or family farm without any remuneration, it was statistically invisible for women and "others" (family); this led to labour practices, family relationships, and images of women and family that expressed a traditional gender division of work (Deere 2006, FAO 2007, Valdés 2007). In contrast, the progressive participation of women in the labour market contributes to integrating new practices, definitions, and ideas that 
simultaneously bring about individual self-worth and the creation of their own spaces.

The training courses helps a lot because one gets together with people living other realities and learns new things; alone on the farm with little education, this helps a lot to get on better with other people, to not be so reserved, snuffed out, in a corner, and be able to speak. It was difficult for me at first. (Mirna, 52 years old)

Through their work, women participate in a group with similar concerns, and obtain financial support to initiate their economic activity, which establishes new self-worth, emotions, and feelings. This growing visibility and self-worth inevitably open a space for change in the perception they have of themselves and the internal family organisation because of their new position. However, there are body/individual changes.

In the women's narratives, body is the first to register the tensions and efforts to cope with daily life. Narratives of women micro-entrepreneurs perceive a demanding, tiring, and overburdened body experience, which expresses in various ways that the body is the carrier of a cultural experience. The body tries to speak, show tension, pain, and exhaustion. Bodily metaphors describe the obvious imbalance in the productive and reproductive roles against which the body reacts; "I am like a machine", "the body does not respond", and "sometimes the body cannot keep up" are expressions that women use to refer to their own experience. They develop very demanding strategies to coordinate both spheres; in most cases the strategy has been a greater personal effort.

When we started to go out, the effort was double since one had to do it all; we had to do the farm chores and get up at six in the morning to prepare lunch, do the cleaning, everything so that our absence would not be felt [...]. (María, San Ignacio Discussion Group)

It should be mentioned that a more acute effect of the transformations the body suffers has to do with the risk involved in the work. The use and handling of fertilizers has permanently affected the participants in the form of diseases.

\section{Family/Home Scale}

No doubt transformations are felt on the family scale and these are assumed as a result of responsibilities and public networks; they are inevitably accompanied by new tensions within the family that women consider as their own gender issues. Husbands or partners frequently resist this productive role because it is seen as a threat to family order and also as a loss of control over women's lives. This resistance is more pronounced if work requires leaving the home for training courses or work meetings.

We are able to convince our partners with much conversation; therefore, I think that all this generates dialogue as well as conflicts, but which are 
solvable (Woman 1. San Ignacio Discussion Group), the outings were the most difficult [...] (Sonia, San Ignacio Discussion Group) [...] he did not like my being absent from home because now it is like a lost cause. (Myriam, San Ignacio Discussion Group)

Principles such as freedom and individual autonomy emerge in the women's discourse and practices although they always contradictorily coexist with their commitments to childcare and domestic responsibilities. This is consistent with the point raised by Guadarrama and Torres (2005) regarding the importance of remunerated work as a key area of meaning for women, which does not replace but rather is intertwined with the family environment making them central concepts of their gender identities; it would therefore be a "double identity ascription".

A current strategy in the discourse of some women micro-entrepreneurs is to include husbands in the productive project to reduce tensions and clashes A current strategy in the discourse of some women micro-entrepreneurs is to include husbands in the productive project to reduce tensions and clashes between family and work activities and transform it into a family project. It is thus a work/family compatibility strategy that does not affect established family arrangements, achieves gradual transformations and validates their productive projects in the presence of their husband or partner.

I believe that it was different in our specific case because we integrated our husbands in the group... and there was good bonding between us; therefore, more or less all of the same age, there is little age difference between one and the other, so husbands were also integrated and became friends which made it something like a family group. (Patricia, Coihueco Discussion Group)

Some break-ups also obliged rethinking experienced situations and established arrangements. Here, the idea of conflict is fundamental to the extent that these discourses are not a profound change in the restructuring of the home since the distribution of tasks is still asymmetric. We are suggesting, according to Jelin (2006), that the change in economic participation shows that there are various forms of "gender empowerment".

However, men have also changed because they have told me many times not to be concerned with food or such because he can prepare something by himself. (Isabel, San Ignacio Discussion Group)

This new type of relationship is integrated in common life or "family" projects, while maintaining the individuality of each member. In either case, it is perceived that the relationship between man and woman in the home is now taking on a different dimension in how rural women that work productively are perceived. The man is the husband and head of the household, but the relationships are perceived with more equality or companionship; the latter is supported by complementary roles, while women emphasise that their 
economic contribution is particularly important during periods of low agricultural returns.

\section{Community/Local Scale}

For this group of micro-entrepreneurs, their flower enterprise is seen as a local work opportunity that is different from those they traditionally have had as women peasant farmers. That is, they had access to precarious, temporary, and badly remunerated work, whereas work in the micro-enterprise takes place on the family farm and there is no abrupt breakdown of family responsibilities.

That is, the opportunities that were had on the farm, which I took as an opportunity to work, followed by another and another and one takes them because they are opportunities that are given; because if one wants to do other things, one has to migrate or leave [...] one has to go to the city or leave to be able to work; therefore, it was not an option, I could not leave my family because of my child, my husband, so one had to organize oneself on site in one's circle. (Carmen, San Ignacio Discussion Group)

This narrative leads us to consider the dual role of women as workers and main reproductive agents; it tends towards strong tensions when crossing the closed limits of the home and family farm since male control and dominance over these spaces forces "asking" permission and justifying absences from the home. In this respect, domestic arrangements to be able to attend meetings, training courses, and fairs are obstacles as well as opportunities to negotiate. Lines of meaning appear that suggest some break-ups concerned with reorganising the productive and reproductive roles of men and women in the home, which refer to women exercising their ability as agents to broaden their life options and take their own decisions as a sign of certain cultural changes.

Noooo, if it was difficult to give in, it was difficult, difficult; that is why I tell you that the man is very sexist and this was so engrained that the women was at home and could not go out, therefore, one must show facts [...] I demonstrated it with facts, I go because I need the training, and that is where one faces the consequences, but I did it. (Mirna, 52 years old)

This is how the organisational process has implied constructing different spaces and times for the home and farm, other social spaces that shape relationship networks that are connected in the use of places, shifts that make up local, regional, and national communication networks. In our case study, the passage of a group of women from the farm to a micro-enterprise allowed them to discover themselves as stakeholders, conscious subjects, and as an influence expanding towards the local community through a shared productive project.

The "micro-enterprise" for this group of women becomes a unique and different shared space, "in the real sense, not only a metaphor, to have space means to have freedom, freedom to direct, to be, to be in contact, and vice versa" (Signorelli 1999: 53). This forms a space with great symbolic value and 
expresses prestige, status, and position with respect to other groups, organisations, and local networks; at the same time, it is a place for creating meaning, a radius of autonomous action where they re-imagine their lives and reconstruct their collective identities.

\section{Conclusions}

The inclusion of women in the workplace is not only "a topic for women"; neither is the promotion of greater gender equity in the work environment and micro-enterprises. It is an opportunity for growth and development of an important part of the country and their families. Indeed, the entrepreneurial option represents personal and family subsistence and sustainability for an ever-increasing number of women, particularly in rural sectors. Progress towards the contribution of women to the home can make the difference between a household being poor or not. In addition, work in its different forms offers new ways of womanhood, and the micro-enterprise provides access even in conditions that could be disadvantageous because of age, children at home, education, religion, and institutional selection.

It is essential to introduce a gender vision in these matters and in social policies. The progress achieved is beyond doubt, including gender equity, but productive public policies for micro-enterprises still need to be widely promoted. These policies must consider the limitations experienced by rural micro-enterprises, but also view gender aspects that affect female work. There is therefore a pending challenge for public policies or agencies that support micro-entrepreneurship and refer to permanent interventions in this aspect. This is crucial for all types of micro-enterprises and more so in the case of those led by women generally faced with issues of caring for children and the elderly. Based on this, a long-standing discussion refers to the issue of integrating social policies that somehow reflect the analysed figures and women's narratives of this case study.

In summary, we believe it is essential to assume that we are dealing with rural women's micro-enterprises, the effects of which go beyond what is merely productive and are extended to transformations in family arrangements, networking, and spatial mobility, which result in identity reconstruction and personal satisfaction with the entrepreneurial option taken. 


\section{References}

Amorós JE, Guerra M, Pizarro O, Poblete C (2011) Mujeres y Actividad Emprendedora en Chile 2010-2011 [Women and Entrepreneurship in Chile 20102011]. Santiago: Global Entrepreneurship Monitor, GEM/Universidad del Desarrollo.

Anthopoulou T (2010) Rural women in local agrofood production: Between entrepreneurial initiatives and family strategies. A case study in Greece. Journal of Rural Studies (26): 394-403.

APEC-Asia-Pacific Economic Cooperation (2009) Public Policies to Promote Women Entrepreneurs Project. Cases of Australia, Canada, Chile And Peru. Singapour: Ministerio de la Mujer y Desarrollo Social del Perú.

Bebbington A, Sotomayor O (1998) Demand-led and poverty-oriented...or just subcontracted and efficient? Learning from (semi-) privatized technology transfer programmes in Chile. Journal of International Development 10(1): 17-34.

Bebbington A (1997) New states, new NGOs? Crises and transitions among rural development NGOs in the Andean region. World Development 25(11): 17551765

Berdegué J (2001) Cooperating to compete. Associative Peasant Business Firms in Chile. La Haya: CIP-DATA Koninkluke Bibliotheek

Chiappe M, Zapata E (2010) Expresiones Locales en Contextos Globales. Una Mirada a Tres Comunidades de Tlaxcala [Local Expressions in Global Contexts. A Look at Three Communities in Tlaxcala]. México: Plaza y Valdes Ed.

Daeren L (2001) Enfoque de género en la política económica-laboral. El estado del arte en América Latina y el Caribe [Gender approach in economic-labor policy. State of the Art in Latin America and Caribbean]. Serie Mujer y Desarrollo(29): 80.

Deere CD (2006) La feminización de la agricultura? Asalariadas, campesinas y reestructuración económica en la América Latina rural [Feminization of agriculture? Employed, farmers and economic restructuring in rural Latin America]. ALASRU: Análisis Latinoamericano del Medio Rural 4: 77.

Escobar G (2002) La Extensión y los Servicios de Apoyo: Hacia una Agricultura Sostenible. Experiencias Seleccionadas y Visión del Cono Sur [The Extension and Support Services: Towards Sustainable Agriculture. Selected Experiences and Vision of the Southern Cone]. Santiago, Chile: RIMISP.

FAO (2007) Situación de las Mujeres Rurales [The Situation of Rural Women]. Retrieved from www.fao.org.

Fawaz J, Rodríguez C (2013) Mujeres rurales y trabajo en Chile Central. Actitudes, factores y significaciones [Rural women and work in Central Chile. Attitudes, and meanings factors]. Cuadernos de Desarrollo Rural 10(72): 47-68.

Fawaz J, Vallejos R, Tolón A, Lastra X (2012) Redefining local participation in sustainable rural development in Chile: the case of small farmers in Nuble province. International Development Planning Review 34(3): 241-264.

Fawaz MJ, Rivera R (1986) Comunidades Rurales de la Provincia de Nuble [Rural Communities in the Province of Nuble]. Chillán: Departamento de Acción Rural y Grupo de Investigaciones Agrarias.

Fawaz MJ, Soto P (2012) Mujer, trabajo y familia. Tensiones, rupturas y continuidades en sectores rurales de Chile central [Women, work and family. Tensions, ruptures and continuities in rural areas of central Chile]. Revista de Estudios de Género la Ventana (35). 
García B, De Oliveira O (2004) Trabajo Extradoméstico Femenino y Relaciones de Género. Una Nueva Mirada [Extradomestic Female Labor and Gender Relations. A New Look]. México: Colegio de México.

Giraldo O (2010) Campesinas construyendo utopia: mujeres, organizaciones y agroindustrias rurales [Peasants building utopia: women, rural organizations and agribusiness]. Cuadernos de Desarrollo Rural 7(65): 43-61.

GORE-Gobierno Regional del Bío-Bío (2010) Resumen Ejecutivo Propuesta "Política Para el Sector Agroalimentario de la Región del Bío-Bío" [Executive Summary Proposal "Policy for the Food Industry in the Region of Bio-Bio"]. Concepción: División de planificación y desarrollo regional.

Godoy L, Stecher A, Díaz X (2007) Trabajo e identidades: continuidades y rupturas en un contexto de flexibilización laboral [Work and identities: continuities and ruptures in the context of labor flexibility]. En Garza E (comp.). Teorías Sociales y Estudios del Trabajo: Nuevos Enfoques. [In Garza E (ed.). Social Theories and Labor Studies, New Approaches]. Barcelona: Anthropos.

Guadarrama R, Torres JL (2005) Identidades laborales en transición. Costureras en Costa Rica y maestras de primaria en México [Work identities in transition. Seamstresses in Costa Rica and primary school teachers in Mexico]. Revista Centroamericana de Ciencias Sociales II.

Guadarrama R, Torres JL (2007) Los Significados del Trabajo Femenino en el Mundo Global. Estereotipos, Transiciones y Rupturas [The Meanings of Women'S Work in the Global World. Stereotypes, Transitions and Ruptures]. Barcelona: Anthropos.

INE-Instituto Nacional de Estadisticas (2002) Censo de Población y Vivienda Santiago [Census of Population and Housing in Santiago].

Jelin E (2006) Pan y Afectos. La Transformación de las Familias [Bread and Affections. The Transformation of Families]. Buenos Aires: Fondo de Cultura Económica.

Jiménez G, Belén A (2005) Modelos y Realidades de la Familia Actual [Models and Realities of the Current Family]. Madrid: Fundamentos.

MINAGRI-Ministerio de Agricultura de Chile (2009) Situación de las Mujeres en el Sector Silvoagropecuario. Avances y Desafios Pendientes en Materia de Equidad de Género [The Situation of Women in the Agriculture and Forestry Sector. The Progress and Remaining Challenges in Gender Equity]. Santiago: Qualitas Agro Consultores: 96

OIT/SERCOTEC (2010) La Situación de Micro y Pequena Empresas en Chile [The Situation of Micro and Small Enterprises in Chile]. Santiago.

Pucheu C (2009) Informe del Departamento de Acción Rural 1976-2006 [Report of the Department of Rural Action 1976-2006]. Obispado de Chillán: Mimeo.

SERNAM-Servicio Nacional de la Mujer (2008). Mujer y Microempresa en Chile [Women and Microenterprise in Chile]. No. 112. Santiago.

Signorelli A (1999) Antropología Urbana [Urban Anthropology]. Barcelona: UAMIztapalapa, División de Ciencias Sociales y Humanidades y Anthropos.

SELA-Sistema Económico Latinoamericano y del Caribe (2010) Desarrollando Mujeres Empresarias: La Necesidad de Replantear Políticas y Programas de Género en el Desarrollo de Pymes [Developing Women Entrepreneurs: The Need to Rethink Gender Policies and Programs in Developing SMEs]. No. 55. Caracas: Secretaria Permanente del SELA.

Smith N (1993) Homeless/global: Scaling places. In Bird CJ, Putnam B, Robertson T, Tickner, GYL (edn.). Mapping the Futures: Local Cultures, Global Change. New York: Routledge. 
Soto P, Fawaz MJ (2006) Nuevas Realidades, Imágenes y Significaciones de la Familia Rural en Chile: Entre la Continuidad y el Cambio [New Realities, Images and Meanings of the Rural Family in Chile: Between Continuity and Change]. Paper presented at the Seventh Congress of the Latin American Association of Rural Sociology (ALASRU), 20- 25 November].

Tarrés ML (2007) Las identidades de género como proceso social: rupturas, campos de acción y construcción de sujetos [Gender identities as social process: ruptures, scopes and construction of subjects]. En Garza E (comp.). Teorías Sociales y Estudios del Trabajo: Nuevos Enfoques [In Garza E (edn.). Social Theories and Labor Studies, New Approaches]. Barcelona: Anthropos.

Uphoff NT, Esman MJ, Krishna A (1998) Reasons for Success: Learning from Instructive Experiences in Rural Development. Hartford: Kumarian Press (p. 6487).

Valdés X (2007) La Vida en Común. Familia y Vida Privada en Chile y el Medio Rural en la Segunda Mitad del Siglo XX [The Common Life. Family and Private Life in Chile and Rural Areas in the Second Half of the Twentieth Century]. Santiago: LOM.

Valenzuela ME (2005) (Ed.) ¿Nuevo sendero para las mujeres? Microempresa y género en América Latina en el umbral del siglo XXI [New trail for women? Microenterprise and gender in Latin America in the twenty-first century]. Santiago: LOM/CEM.

Vera MB, Moreira V (2009) Caracterización de la microempresa agrícola del sur de Chile [Characterization of agricultural microenterprises in southern Chile]. IDESIA 27(3): 89-99. 